\title{
SZÉLl GÁBOR
}

szellgabor1@gmail.com

doktorjelölt (SZTE BTK)

\section{Eretnekség és igazhitúség az 5. századi Gallaeciában}

\section{Heresy and Orthodoxy in Gallaecia in the 5th Century}

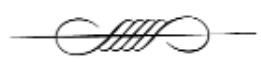

\begin{abstract}
Hydatius' Chronicle offers a detailed account of the history of 5th century Hispania and the disintegration of imperial power, and with respect to Gallaecia's church hierarchy it is the only source available. Hydatius fought against barbarians and heretics all his life and as a bishop in Gallaecia, he relentlessly battled with the enemies of the Hispano-Roman population and orthodoxy. Yet heretical teachings gained immense popularity with the Roman population and bishops alike, owing to weak imperial power and the fluctuating nature of political protection Catholic faith received. The focus of this study is to examine how it was possible in 5 th century Gallaecia for Priscillianist beliefs, themselves the cause even of political scandal, to spread so rapidly, how they led to the loosening of church discipline and scandallous elections of bishops, and ultimately, how these processes affected the activity of Hydatius as a bishop and his view of history unfolding in the Chronicle.
\end{abstract}

\section{KEYWORDS}

Hydatius, history of 5th century, Hispania, Gallaecia, heretics, orthodoxy, Priscillianism

DOI 10.14232/belv.2019.1.10 https://doi.org/10.14232/belv.2019.1.10

Cikkre való hivatkozás / How to cite this article: Széll Gábor (2019): Eretnekség és igazhitüség az 5. századi Gallaeciában. Belvedere Meridionale 31. évf. 1. sz. 150-165. pp.

ISSN 1419-0222 (print)

ISSN 2064-5929 (online, pdf)

(Creative Commons) Nevezd meg! - Így add tovább! 4.0 (CC BY-SA 4.0)

(Creative Commons) Attribution-ShareAlike 4.0 International (CC BY-SA 4.0)

www.belvedere-meridionale.hu 
Hydatius Chronicája részletes beszámolót nyújt számunkra az 5. századi Hispania történetéről és a császári hatalom felbomlásáról, Gallaecia egyházi szervezetével kapcsolatban pedig ez az egyetlen forrás áll rendelkezésünkre. Hydatius egész életében a barbárok és az eretnekek ellen harcolt, gallaeciai püspökként kitartóan szállt szembe a hispán-római lakosság és az ortodoxia ellenségeivel. A császári hatalom gyengesége és a katolikus hit politikai védelmének változó intenzitása azonban azt eredményezte, hogy az eretnek tanítások rendkívül nagy népszerűséget szereztek a római lakosság és a püspökök körében egyaránt. Tanulmányunkban azt vizsgáljuk, hogy az 5. századi Gallaeciában miért terjedhettek ilyen gyorsan a politikai botrányt is kavaró priscillianus eszmék, hogyan okozhatta ez az egyházi fegyelem lazulását és a botrányos püspökválasztásokat, végül pedig az előbbi folyamatok milyen hatást gyakoroltak Hydatius püspöki tevékenységére és a Chronicában kibontakozó történelemszemléletére.

Hydatius a gallaeciai Lemicában született 400 körül, ${ }^{1}$ szülei feltehetően keresztények voltak és Hispania társadalmának jómódú középosztályába tartoztak, apja valószínűleg állami vagy katonai hivatalt töltött be. ${ }^{2}$ Többen feltételezték, hogy Hydatius családja rokonságban állt azzal a priscillianus-ellenességéről ismert Hydatiusszal, aki a lusitaniai Emerita püspöke volt a 4. század második felében, de erre a névazonosságon kívül semmi sem utal. ${ }^{3}$ Ha rokonok lennének, Hydatius minden bizonnyal említette volna híres elődjét a priscillianusokkal kapcsolatban. ${ }^{4}$ Nem lehet azonban véletlen, hogy az emeritai Hydatiusról a következő nemzedékben két püspököt is elneveztek: az egyiket Gallaeciában, a másikat pedig Galliában, éppen a priscillianus-mozgalom két nagy központjában. ${ }^{5}$ Ezek alapján valószínű, hogy a szülők csupán Hydatius iránti tiszteletük jeléül nevezték el így gyermeküket, és nem álltak vele semmilyen rokoni kapcsolatban. ${ }^{6}$ Hydatius 406-407 körül kisfiúként részt vett egy szentföldi peregrinatión, ${ }^{7}$ ahol rendkívül nagy hatást gyakorolt rá, hogy látott jó néhány híres, a krónikában is említett püspököt, mindenekelőtt Hieronymust. ${ }^{8}$ Szülei feltehetően igyekeztek alapos nevelést biztosítani számára, amelyhez hozzátartoztak a nagyobb utazások és talán az irodalmi tanulmányok is, ${ }^{9}$ azt viszont nem tudjuk, hogy az ortodox nevelésen kívül részesült-e valamilyen vallási képzésben, ${ }^{10}$ mindenesetre még 409 októbere előtt vissza kellett térnie Gallaeciába, amikor az alánok, a vandálok és a szvévek betörtek Hispaniába. ${ }^{11}$

\footnotetext{
${ }^{1}$ Hyd. praef. 1. Lemica civitas vagy civitas Limicorum, ma Nocelo da Pena városa Hispania Tarraconensis területén, 12 kilométerre Xinzo de Limiától, vö. BuRgESs 1988. 6.

${ }^{2}$ Ha Hydatius családja a társadalom alsó rétegéhez tartozott volna, nem valószínű, hogy később püspökké szentelhették volna, vö. Tranoy 1974. 1.10; ARIAs 2007. 4.

${ }^{3}$ Burgess 1993. 3.

${ }^{4}$ Hyd. 13; 16.

${ }^{5}$ Leo Ep. 99; Hilar. Ep. 10; Burgess 1988. 8; MuHLberger 1990. 198.

${ }^{6}$ Burgess 1993. 4.

${ }^{7}$ CAndelas-Colodrón 2004. 77-85.

${ }^{8}$ Hyd. praef. 4; 33.

${ }^{9}$ Muhlberger 1990. 199.

${ }^{10}$ Bár a későbbi püspökké szentelésnek nem volt feltétele a vallási területen szerzett képzettség, elképzelhető, hogy Bracarában vagy Aquae Flaviae városában a helyi püspök foglalkozott Hydatiusszal, vö. BuRGESs 1988. 199.

${ }^{11}$ Hyd. 34.
} 
Több kutató szerint 416-ban megtért és elkezdett vallásos életet élni, ${ }^{12}$ később pedig a helyi közösség életében nagy tekintélyt kellett szereznie, mert 427-ben, alig harminc évesen ${ }^{13}$ püspökké választották Aquae Flaviae városában. ${ }^{14}$ Amikor 431-ben a szvévek Gallaeciába szorultak vissza és fosztogatni kezdték a hispán-római lakosságot, Hydatius bekapcsolódott a politikai életbe és követséget vállalt a Galliában hadjáratot tartó Aëtiushoz; 432-ben Censoriusszal, a császári követtel tért vissza, egy évvel később pedig megerősítette a gallaeciabeliekkel kötött békét. ${ }^{15}$ 445-ben Thoribius, Asturica új püspöke Leo pápa támogatásával Hydatius és Caeponius segítségét kérte levélben a manicheusok elleni küzdelemhez. ${ }^{16}$ A két püspök lelkesen kutatta fel a bujkáló manicheusokat, közülük jó néhányat fel is jelentettek Antoninusnál, Emerita püspökénél. ${ }^{17}$ Thoribius 447-ben Leo pápától ismét segítséget kért az eretnekek elleni küzdelemhez. Ebben az elveszett levélben ${ }^{18}$ minden bizonnyal megnevezte munkatársaként Hydatiust, mert Leo Thoribiusnak írt 447. július 21-ei válaszában ${ }^{19}$ már név szerint kérte Hydatius és Caeponius segítségét a priscillianizmus visszaszorításában és a katolikus hit helyreállításában. ${ }^{20}$

Hydatius életének minden szakaszában, a gyerekkori zarándoklattól a püspökké szentelésen át egészen az eretnekségek elleni harcig az egyház által hirdetett szigorú ortodoxiát támogatja, és nemcsak önmagától, hanem másoktól is elvárja az egyházi fegyelmet és az egyetlen helyes tanítás védelmezését. ${ }^{21}$ Számos olyan eretnekséget említ a krónikában, amelyik Hispaniában nagy népszerűséget szerzett és veszélyeztette a katolikus hit egységét, nem véletlen, hogy a legtöbb vallásra vonatkozó feljegyzés az eretnekmozgalmak elleni harchoz kapcsolódik. ${ }^{22}$ Muhlberger szerint Hydatius az arianusok, a priscillianusok és a manicheusok mozgalmával foglalkozik

${ }^{12}$ ThOMPSON 1982. 139; CAMPOS 1984. 64. Burgess interpolatiónak tartja, ezért elutasítja Flórez erre vonatkozó feljegyzését, amely a krónika 570-es években készített epitoméjában szerepel, vö. Hyd. 62b; BuRGESs 1988. 14.

${ }^{13}$ Hyd. praef. $1 ; 6$.

${ }^{14}$ Hyd. praef. 1; praef. 6. Thompson kétségbe vonja Mommsen azon feltételezését, hogy Hydatius Aquae Flaviae püspöke lett volna, mivel szerinte a városnak sohasem volt püspöki rangja, és csak annyit ismer el, hogy Hydatius egy „eminent churchman” volt, vö. THOMPSON 1982. 140. Muhlberger azt feltételezi, hogy a város püspöki székét a 6. század eleji zürzavaros helyzetben szüntették meg, vö. MuHLberger 1990. 197. Aquae Flaviae korabeli helyzetéről lásd: CANDELAS-COLODRÓN 2004. 143-152.

${ }^{15}$ Hyd. 86; 88; 91.

${ }^{16}$ Thor. Ep. ad Hyd. et Cep., in PL 54.693-695.

${ }^{17}$ Hyd. 122.

${ }^{18}$ Muhlberger 1990. 195.

${ }^{19}$ Leo Ep. 15.17, in PL 54.677-692.

${ }^{20}$ Hyd. 127.

${ }^{21}$ Burgess 1988. 194; vö. Hyd. praef.; 1; 29; 79; 110; 112; 127; 129; 228.

${ }^{22}$ Az eretnekségek terjedésével (ex furentium dominatione) magyarázza, hogy a katolikus vallás nehéz helyzetbe került, Hieronymus munkái közül pedig azokat emeli ki, amelyek eretnekségek ellen (adversum alios hereticos) íródtak, vö. Hyd. praef. 6; 51. Részletesen beszámol arról, hogy a gnosztikus eretnekség felé forduló (declinans in heresem gnosticorum) Priscillianust hiába nyilvánították eretnekké (hereticus iudicatus), eretneksége (heresis) mégis átterjedt Gallaeciába, ezért Hydatius többször is istenkáromló eretnekségnek (heresem blasphemissimam) és veszedelmes szektának (sectam perniciosissimam) nevezi mozgalmukat, vö. Hyd. 13; 16;25; 127; 30. Az arianizmusra különös módon egyetlen alkalommal sem utalt ezzel a szóval, helyette hitetlenségnek (Arrianam perfidiam), kegyetlenségnek (impietatem Arrianam) és veszedelmes méregnek (pestiferum virus) tartja tanításukat, a nestorianusok nézeteit viszont téves elnevezéssel ugyan, de többször is az elpusztítandó eretnekségek (ad destruendam Hebionitarum heresem) közé sorolja, vö. Hyd. 79; 112; 228; 97; 100; 137. 
a legtöbbet, mert ezek Gallaeciában is sok támogatót szereztek, ugyanakkor egyáltalán nem említi a gallaeciai pogányságot, holott a vidéki területeken még nagyon erősen kimutatható a jelenléte. ${ }^{23}$ Ennek az lehet a magyarázata, hogy Hydatius úgy látta püspökként, hogy az ortodox lakosság inkább hajlamos áttérni az arianus vagy priscillianus tanításra, mint csatlakozni a pogány eszmékhez. Hydatius az eretnekmozgalmak említésekor meg sem próbálta magyarázni a tanításukat, nem érdeklődött az eretnekségek fejlődése iránt sem, több alkalommal még össze is keverte a mozgalmakat, emiatt feltételezhető, hogy nem azért harcolt ellenük, mert nem értett egyet a tanításukkal, hanem azért, mert azok gyengítették az ortodoxia helyzetét és válságba sodorták a birodalmi irányítást. ${ }^{24}$

Mivel Hydatius a priscillianusok mozgalmáról írt a legrészletesebben, feltehetően az ő fenyegetésüket találta saját korában a legveszélyesebbnek. Burgess szerint Hydatius kiállása az ortodoxia mellett azért is egyedülálló, mert az 5. századi Gallaecia lakosságának nagy része priscillianus lehetett, ${ }^{25}$ ennek ellenére a szerző rendkívül higgadtan tárgyalja a priscillianizmussal kapcsolatos eseményeket. Miután 370 körül Hispaniában feltűnt egy Priscillianus nevű laikus szerzetes, és szigorú erkölcsei és szélsőséges aszkézise miatt ${ }^{26}$ gyorsan szerzett tanítványokat a nemesség, a nők és a püspökök között, ${ }^{27}$ mozgalma a 370-es évek végére már Hispanián kívülre is eljutott.

Amikor a cordubai Hyginus feljelentése miatt Hydatius emeritai püspök rendkívül hevesen lépett fel Priscillianus követőivel szemben, azok hitvallásukkal igyekeztek megcáfolni a manicheizmus és a gnoszticizmus vádját. 378-ban Damasus pápához is eljuthatott a mozgalom híre, mert 380. október 4-ére összehívta a caesaraugustai zsinatot, ahol a tanácskozáson részt vevő 12 püspök a priscillianusok ellen hozott döntéseket, többen viszont szimpatizáltak a mozgalommal. ${ }^{28}$ Priscillianus néhány követője igyekezett megbékíteni az emeritai Hydatiust, de amikor a püspök az ossonubai Ithacius javaslatára nem fogadta őket, 381-ben a jóváhagyása nélkül emelték társai Priscillianust Avila püspökévé, figyelmen kívül hagyva ezzel mindenféle püspökszentelést szabályozó rendeletet. ${ }^{29}$ Miután az emeritai Hydatius jelentést küldött erről Gratianusnak és a nagy befolyással rendelkező mediolanumi Ambrosiusnak, Aquitaniába száműzték a priscillianus püspököket, ezért Priscillianus Rómába sietett, hogy a pápától kérjen segítséget. Damasus, a burdigalai Delphinus püspök és Ambrosius azonban nem volt hajlandó fogadni őt, ${ }^{30}$ az egyik mediolanumi magister officiorum megvesztegetésével viszont vissza tudta szerezni hivatalát, ${ }^{31}$

${ }^{23}$ Muhlberger 1990. 235. A gallaeciai pogányság müködéséről lásd: MolÉ 1975. 94-96.

${ }^{24}$ Hyd. 228; Burgess 1988. 205; 214.

${ }^{25}$ Burgess 1988. 194; 206.

${ }^{26}$ Priscillianus szembeszállt a dogmákat felállító egyházi tanítással és a dogma nélküli kereszténység eszméjét hirdette, elvetett mindenféle törvényt és egyházi hierarchiát, népszerüsítette az apokrif iratokat, vö. LÖHR 2007. 38. Priscillianus működéséről és tanításáról részletes összefoglalót nyújt: BuRRUs 1995. 103-126; SPÄT 1998. 137-152; HORVÁTH 2004. 67-81.

${ }^{27}$ Hyd. 13. Instantius és Salvianus lusitaniai püspökök például esküvel kötelezték el magukat Priscillianus mellett, vö. BuRgess 1988. 195.

${ }^{28}$ RANDERS-PEHRSON 1993. 122. A konkrét döntések hátteréről bővebben: CHADWICK 1976. 12-15; HoRVÁTH 2004. 70-72; PL 84.315-318.

${ }^{29}$ Hyd. 13. Avila püspöki székéről nem sokat tudunk, Priscillianus megválasztása előttről nincs is róla információnk, legközelebb pedig csak 610-ben említik a várost, vö. BURGESS 1988. 16.

${ }^{30}$ Hyd. 13.

${ }^{31}$ Burgess 1988. 195. 
emiatt adódhatott az a különös helyzet, hogy Priscillianus ellenfeleit, többek között az emeritai Hydatiust és Ithaciust ítélték el a hispaniai egyház felforgatása miatt.

Gratianus halála után 384-ben Magnus Maximus usurpator és társcsászár zsinatot hívott össze Burdigalában a priscillianusok elítélésére, ${ }^{32}$ ahol eretnekké nyilvánították Priscillianust, de ő nem jelent meg a tanácskozáson, inkább felmentésért fellebbezett Maximushoz. ${ }^{33}$ A világi bíróság Treveriben mágiával vádolta meg Priscillianust és kínvallatással beismerő vallomásra késztette az eljárás során. Bár Martinus Turonensis és Ambrosius más püspökökkel együtt azt javasolta Maximusnak, hogy mivel a vallási kérdések elbírálása kizárólag a püspöki törvényszékek hatáskörébe tartozik, világi ítélet alapján semmiképpen se végezzék ki Priscillianust, ${ }^{34}$ 385-ben ${ }^{35}$ a császár mégis lefejeztette őt hat társával együtt, ${ }^{36}$ köztük említ Hydatius egy Latronianus nevü papot, másokat pedig számüztek. ${ }^{37}$

Priscillianus és követői voltak valószínüleg az első olyan eretnekek, akikkel szemben a világi hatalom halálos ítéletet hozott, ${ }^{38}$ ezért kivégzésük politikai körülményei és a bírói hatalommal való visszaélés nagy megosztottságot eredményezett az egyházon belül. Martinus Turonensis azt javasolta, hogy az egyház és az állam is foglalkozzon a saját ügyeivel, Ambrosius és az időközben trónra lépő Siricius pápa pedig a Priscillianus elítéléséért küzdő püspököket okolta a történtekért, és megtagadták a közösséget az ügyet elindító hispaniai püspökökkel. ${ }^{39}$ Heves tiltakozásuk olyan sok támogatóra talált, hogy végül megfosztották hivataluktól azokat a püspököket, akik hozzájárultak a halálos ítélet kimondásához. ${ }^{40}$ Maximus túlkapását sokáig azzal magyarázták, hogy a halálra ítéltek vagyonelkobzása miatt jelentős vagyonra tett szert az eljárás végén, a források viszont Hydatiushoz hasonlóan azt igazolják, hogy a kortársak Priscillianus követőit a manicheusokkal vagy a gnosztikusokkal azonosították. ${ }^{41}$ Maximus velük szembeni határozott fellépése tehát megfelelt a katolikus püspökök elvárásainak, így a hit elkötelezett védelmezőjeként a politikai pozíciója megerősödését is remélhette. ${ }^{42}$

Feltűnő módon viszont sem Damasus és Siricius pápa, sem Ambrosius nem mondott nyíltan véleményt Priscillianus ügyében. Damasus idején Róma tekintélye még tovább növekedett a többi egyházi központhoz képest, ezért elvárható lett volna, hogy a pápa kifejezze véleményét egy ilyen kritikus és megosztó kérdésben, a gyors döntéseiről híres Ambrosiusnak pedig az arianusok

${ }^{32}$ Gratianus halálának körülményeiről és Maximus esetleges szerepéről lásd: Socr. 5.11; Sozom. 7.13.8; Ambr. Ep. 24.10; Pac. Paneg. 24; SzÉKELY 2018. 104. 22. j. Maximustól a Galliába menekült Ithacius kért segítséget az igaz hit védelmében, vö. BuRGESS 1988. 195.

${ }^{33}$ Hyd. 13.

${ }^{34}$ Ambr. Ep. 26.20; LyMAN 2007. 308; SÁRY 2009. 122.

${ }^{35}$ Az események pontos datálásához lásd: CHAdwick 1976. 132-138; BuRGess 1988. 196. 2. j.

${ }^{36}$ Sulp. Sev. Chr. 2.51; RANDERs-PeHRSON 1993. 33.

${ }^{37}$ Hyd. 16. Valójában először csak Priscillianust és 4 követőjét végezték ki, később Hispaniában még 2 kivégzésre került sor, vö. Pac. Paneg. 28-29; Ambr. Ep. 24.11; Hier. De vir. ill. 122; Sulp. Sev. Chr. 2.51; LÖHR 2007. 39; SzÉKELY 2018.106.

${ }^{38}$ SZÁNTÓ 1983. 166; SEGESVÁRY 1994. 80.

${ }^{39}$ Hyd. 15; Ambr. Ep. 30.12; Sulp. Sev. Chr. 2.50; CHADwiCK 1976. 145-148; 151-152.

${ }^{40}$ Ambr. Ep. 24.12. Az emeritai Hydatius önként mondott le püspöki hivataláról 388 körül, Ithacius pedig 7 évvel később halt meg száműzetésben, vö. BuRGESS 1988. 196.

${ }^{41}$ Hyd. 13; 122; Sulp. Sev. Chr. 2.46-49; CHADwick 1976. 94-99; 194-208.

${ }^{42}$ Horváth 2004. 79-80. 
és a manicheusok elleni harcban talán még kapóra is jött volna, hogy ha segít felszámolni egy újabb eretnekmozgalmat. ${ }^{43}$ García Villada azzal magyarázza a viselkedésüket, hogy mindketten vigyáztak arra, nehogy bármilyen módon is eretnekséggel hozzák őket kapcsolatba, Horváth ezzel egyetértve még két további érvet igazol: mivel Priscillianus követőit manicheusoknak tartották, felesleges lett volna a pápának nyilatkoznia, hiszen a velük szemben alkalmazott szankciók már érvényben voltak, másrészről pedig ha helytelenül is, de világi bíróság döntött a vádlottak ügyében, ezért az egyház vezetői ebbe az ügybe már nem szólhattak bele. ${ }^{44}$ Priscillianus elítélése tehát nemcsak teológiai, hanem erősen politikai üggyé is vált, és az eset szereplői saját pozíciójuk védelmében közreműködtek a koncepciós per lebonyolításában. ${ }^{45} \mathrm{~A}$ Priscillianus ellen felhozott vádakat és elítélésének körülményeit vizsgálva ugyanakkor azt is mondhatjuk, hogy a korábbi arianus vitából eredően a püspökök közötti konfliktusokat még jobban elmélyítette a Priscillianusszal szemben folytatott eljárás, a világi bíróság beavatkozása pedig birodalmi jelentőségűvé növelte a priscillianizmus politikától egyébként sem mentes ügyét. ${ }^{46}$

A Priscillianus kivégzése körüli botrány nagy felháborodást váltott ki a hívek körében, ezért tanításai még nagyobb népszerűséget szereztek, különösen a kevésbé romanizált és lecsúszott rétegek körében Gallia és Hispania déli részén, Baetica és Lusitania területén, ${ }^{47}$ illetve Hydatius beszámolója alapján Gallaeciában is, ${ }^{48}$ arra vonatkozóan viszont nincsenek forrásaink, hogy 385 előtt már voltak-e priscillianusok a területen. Elősegítette a mozgalom terjedését az is, hogy Priscillianus tanítása apokrif és eretnek forrásokra, valamint pogány népszokásokra támaszkodott, ezért a „,eológiailag megmüveletlen talajon” különösen nagy népszerüséget tudott elérni. ${ }^{49}$ A 400 körül megtartott toletumi zsinatról ${ }^{50}$ Hydatius hosszabb beszámolót közöl: a tanácskozáson elítélték a priscillianusokat, és jó néhány gallaeciai püspök, akik korábban Priscillianus követői lettek, visszatértek a katolikus hitre, köztük az asturicai Symphosius és Dictinius nevü fia, aki még külön müvet is írt Priscillianus védelmében. ${ }^{51}$ A zsinat résztvevői között említi Hydatius Aquae Celenae püspökét, Ortygiust is, akit korábban katolikus hite miatt a priscillianusok számüzetésbe kényszerítettek. ${ }^{52}$

Ezt követően egyre nagyobb erőkkel üldözték a priscillianusokat, akik ugyan nem alakítottak ki önálló egyházi hierarchiát, de a tanításukkal rokonszenvező püspökök megválasztása és egyházba való visszatérése állandó feszültséget teremtett, 402-403 körül pedig egyfajta szkizmát is eredményezett a hispaniai egyházon belül. ${ }^{53}$ A szvévek 409-es betörésük és letelepedésük után

\footnotetext{
${ }^{43}$ Horváth 2004. 76-77.

${ }^{44}$ García Villada 1932. 1.2.124-126; HoRvÁth 2004. 80.

${ }^{45}$ HoRVÁth 2004. 68.

${ }^{46}$ ESCRIBANO 2005. 121-149.

${ }^{47}$ Sulp. Sev. Chr. 2.51.4; Augusto 2016. 637; CorTÁZAr - VESGA 2001. 95.

${ }^{48}$ Hyd. 16.

${ }^{49}$ VANYÓ 1999. 152.

${ }^{50}$ A zsinatot valamikor 397-400 között hívták össze, vö. LÓPEz QuIROGA - MARTínEZ TEJERA 2017. 478.

${ }^{51}$ Hyd. 25.

${ }^{52}$ A zsinat eseményeiről bővebben: Vives 1963. 19-33; CHADwick 1976. 170-188; 234-239; D’EMILIO 2015. 229 -230.

${ }^{53}$ CHAdwick 1976. 209; Burgess 1988. 196. A legnagyobb felháborodást valószínüleg az keltette, hogy a priscillianus és az ortodox papok egyaránt áldoztathattak a templomokban, vö. CHADWICK 1976. 153; 181; ugyanakkor azt is tudjuk, hogy a kolostorok jelentős része a priscillianusok kezére került, vö. RıcHÉ 2016. 110.
} 
talán még sajátos védelmet is biztosítottak számukra Gallaeciában, Tranoy ugyanis valószínüsíti, hogy a priscillianusok és a szvévek szövetséget kötöttek egymással, Muhlberger szerint pedig Hydatius szándékosan hallgat erről az egyezségről. ${ }^{54}$ Tranoy feltételezésének viszont ellentmond, hogy a Hermeric által 433-ban a rómaiakhoz küldött Symphosius püspök kronológiai okok miatt nem azonosítható azzal a hasonló nevü püspökkel, aki még a 400 körül megtartott toletumi zsinat előtt priscillianus volt. ${ }^{55}$ Azt is tudjuk azonban, hogy a priscillianus eszmék annyira népszerüek voltak Gallaeciában, hogy ez erősen megkülönböztette a területet Hispania többi tartományától, ezért rendkívül kockázatos lett volna nyíltan fellépni ellenük, és mivel ez Hydatiusnak sem sikerülhetett saját müködési területén, inkább hallgatott a közöttük lévő szövetségről. ${ }^{56} \mathrm{~A}$ szvévekkel való kiegyezés mindenesetre azt mutathatja, hogy a priscillianusok nem ragaszkodtak minden áron az eszméikhez, megmaradásuk érdekében inkább kompromisszumokat kötöttek és kiegyeztek a politikai hatalommal, ${ }^{57}$ ráadásul jó néhány forrásunk is van arra vonatkozóan, hogy a barbárok jelenléte kifejezetten kedvezett az eretnek eszmék terjedésének. ${ }^{58}$

Augusto az irodalmi források és a régészeti bizonyítékok feltérképezésével próbálta kideríteni, hogy mi lehetett az oka annak, hogy a priscillianizmus ekkora népszerüséget szerzett Gallaeciában. Ideológiai magyarázatként elfogadja, hogy a gallaeciaiak patriotizmusát erősíthette a priscillianizmus elfogadása, Cardelle de Hartmann nyomán pedig hangsúlyozza, hogy Priscillianus sajátos jellemvonásai is hozzájárulhattak a mozgalom népszerűségéhez. ${ }^{59} \mathrm{~A}$ vallási magyarázatok között felmerül Priscillianus ereklyéinek ismertsége és a tanítás fejlődésének „,undercurrent”-je is, Chadwick pedig az ortodoxiát képviselő császári hatalom erőtlenségével indokolja az eretnekmozgalom terjedését. A korábbi kutatásokkal szemben Augusto szerint Priscillianus életében és közvetlenül a kivégzése utáni időszakban a felsőbb társadalmi rétegek körében is nagy népszerüséget szerzett a priscillianizmus egy ,, aristocratic movement” formájában, amely akkor veszített újra sok támogatót, amikor a toletumi zsinat nyomán jó néhány megtévedt püspök visszatért az egyházba ${ }^{60}$ Augusto összességében ,, socio-economic” jellegű okokra vezeti vissza a jelenséget, mivel az aszketikus eszméknek hódoló arisztokrata csoportok ellenőrzésük alatt tudták tartani Gallaecia lakosságát, miközben hatalmi harcot vívtak egymással korábbi életformájuk megtartásáért. ${ }^{61}$

Sulpicius Severus valószínűleg azért is írta meg Martinus Turonensis életrajzát, mert a 4. század végén rendkívül sok gondot okozott a priscillianizmus Hispaniában, Augustinus és Orosius pedig a 410-es évek közepétől támadta jó néhány munkában a priscillianusok nézeteit. ${ }^{62}$ Thoribius, Asturica püspöke arról tájékoztatta a fent említett levelében Hydatiust és Caeponiust, ${ }^{63}$ hogy

\footnotetext{
${ }^{54}$ Tranoy 1974. 1.42-45; MuhlBerger 1990. 240.

${ }^{55}$ Hyd. 92; 25; Chadwick 1976. 238; Burgess 1988. 219.

${ }^{56}$ Maldonado 2005. 155; Burgess 1988. 203.

${ }^{57}$ A priscillianizmus és a szvévek viszonyáról bővebben: CARDELLE DE HARTMANN 1998. 81-104.

${ }^{58}$ August. Ep. 166, in CSEL 44; Oros. Comm. 1.3; Leo Ep. 15.16; LóPez Quiroga - Martínez Tejera 2017.479.

${ }^{59}$ Augusto 2016. 635-636; Cardelle de Hartmann 1998. 269-290.

${ }^{60}$ Chadwick 1976. 220-221; Augusto 2016. 640-643.

${ }^{61}$ Augusto 2016. 651.

${ }^{62}$ Augustinus a Liber ad Orosium contra Priscillianistas et Origenistas, Orosius pedig a Commonitorium de errore Priscillianistarum et Origenistarum című munkájában fejtette ki nézeteit.

${ }^{63}$ Thor. Ep. ad Hyd. et Cep., in PL 54.693-695.
} 
utazgatásai során úgy látta a legtöbb provinciában, hogy az egyházi vezetőknek sikerült megfékezniük az eretnekségek terjedését, és a mozgalmakkal szimpatizálók vagy visszatértek a katolikus hitre, vagy számüzetésbe kellett vonulniuk, Gallaeciában viszont a téves tanítások egyre jobban megfertőzték a lakosságot és veszélybe sodorták az ortodoxiát. Úgy tűnik, hogy a gallaeciai püspökök nem vették túl komolyan a katolikus hit védelmét, vagy túlságosan türelmesek voltak az eretnekmozgalmakkal szemben, Thoribius mindenesetre a kialakult helyzetért azokat a püspököket hibáztatja, akik nem tartják be következetesen a pápai utasításokat és fegyelmezetlenségükkel szabad utat engednek az eretnekmozgalmak terjedésének.$^{64}$ Vilella szerint a római császárság és a katolikus hit támogatói még mindig nagyon széles tábort alkottak ebben az időszakban, ezért Thoribius kritikája legfeljebb csak Hispania egészére vonatkozóan lehet helytálló. ${ }^{65}$ Ennél azonban sokkal valószínűbbnek tünik Burgess álláspontja, mely szerint a 440-es évek Gallaeciájában Thoribiuson és Hydatiuson kívül nem sok olyan püspököt találunk, aki teljes mértékben elutasítaná a priscillianus tanításokat, egy kívülálló szemével pedig akár az összes gallaeciabeli priscillianusnak tünhetett, ezért sem véletlen, hogy jó néhányan vallási okok miatt hagyták el a provinciát. ${ }^{66}$

Thoribius már annyira veszélyesnek ítélte meg a helyzetet, hogy a pápától egy hispaniai vagy gallaeciai zsinat összehívására is engedélyt kapott, ${ }^{67}$ de nem tudjuk biztosan, hogy megvalósult-e ez a tanácskozás, mivel Hydatius erről semmit sem nyilatkozik. ${ }^{68}$ Gallaecia püspökei feltehetően nem segítették Thoribius és Hydatius manicheusok elleni küzdelmét sem, mert Leo pápának Hispania-szerte szét kellett küldenie a manicheusokról szóló jelentéseket, 449-ben pedig Flavianus püspökkel folytatott levelezését Cyrill írásával és más jelentésekkel együtt terjesztette az egyházban. ${ }^{69}$ Leo valószínűleg így próbálta egyértelműen a katolikus egyház melletti kiállásra ösztönözni a hitükben megingott gallaeciai püspököket, akiknek egy része még mindig az eretnekek oldalán állt. Leo Thoribiusnak írt válaszában megerősíti feltételezésünket, amikor még borúsabb képet fest a gallaeciai püspökök hűségéről, mert jó néhányan nemcsak hogy nem léptek fel az eretnekekkel szemben, hanem még segítették is a hitük terjesztését. ${ }^{70}$ Burgess azt állítja, hogy Hydatius nem értékelte az eretnekségekkel szembeni küzdelem apróbb sikereit, mert hamis prófétáknak tartotta őket és ezek az események inkább csak fokozták pesszimizmusát, ${ }^{71}$ ha azonban ez így lenne, akkor nem látnánk a krónikában Hydatius kiállását az ortodoxia mellett, és nem buzdítaná ennek követésére a többi püspököt és az olvasókat sem.

\footnotetext{
${ }^{64}$ Muhlberger 1990. 237; 241.

${ }^{65}$ Vilella 1999. 40.

${ }^{66}$ BuRgess 1988. 197-200. Többek között a priscillianizmus megerősödése is közrejátszhatott abban, hogy Orosius elhagyta Gallaeciát, vö. CHADWICK 1976. 191; Oros. 3.20.6-7; 5.2. Bachiarius pusztán gallaeciai származása miatt kényszerült arra, hogy igazhitűségét a pápa előtt igazolja, vö. Bach. De fide 1-2, in PL 20.1019; LóPEz PEREIRA 1998. 30-31; de maga Thoribius is hosszú ideig volt távol püspökké szentelése előtt, vö. Thor. Ep. ad Hyd. et Cep. 1, in PL 54.693; CHADWICK 1976. 209.

${ }^{67}$ Leo Ep. 15.17, in PL 54.677-692; MuHLBerger 1990. 239.

${ }^{68}$ Torres Rodríguez szerint Gallaeciában és Hispaniában is tartottak egy-egy zsinatot, vö. ToRRES RoDRíGUEZ 1977. 102; Thompson csak a gallaeciairól tud, vö. THOMPson 1982. 196; Tranoy és Chadwick viszont jogosan kételkedik abban, hogy bárhol is tárgyaltak volna az eretnekek ügyéről, vö. TRANOY 1974. 2.85; CHADWICK 1999. $216-217$.

${ }^{69}$ Hyd. 125; 137.

${ }^{70}$ Leo Ep. 15.17, in PL 54.677-692; MuHLBERGER 1990. 241.

${ }^{71}$ Burgess 1988. 186.
} 
A kutatók többsége felfigyelt arra, hogy a Hydatius és Caeponius által feljelentett manicheusok ügyét nem a gyakorlatnak megfelelően Bracarában, Gallaecia fővárosában tárgyalták, hanem Emeritában. Mivel Hydatius csak keveset nyilatkozik a bracarai egyházról, Balconius bracarai püspök szerepe pedig még ma is vita tárgyát képezi ${ }^{72}$ az esetet valószínüleg azzal magyarázhatjuk, hogy a legtöbb egyházi vezetővel ellentétben Emerita püspöke, Antoninus határozottan támogatta az eretnekekkel szembeni fellépést, míg Bracara püspöke szimpatizálhatott a manicheusokkal vagy a priscillianusokkal, mivel a város a szvévek igazgatási központjaként funkcionált. ${ }^{73}$ Bár Emerita katonai táborként és igazgatási központként is müködhetett ebben az időben, ${ }^{74}$ a szvévek a jelek szerint nem akadályozták a nyomozásban részt vevő püspökök utazgatását és az eretnekmozgalmak ellen végzett tevékenységüket, ebből következően a 440-es években valószínűleg kevésbé tartották szoros ellenőrzés alatt a római lakosságot. Díaz szerint a szvévek nem is alakítottak ki önálló vallási testületeket és nem akadályozták az újraszerveződő római egyház müködését, hanem hagyták, hogy az egyház igazgatásában és szervezetében függetlenül müködjön, ${ }^{75}$ ahogyan erről a régészeti feltárások eredményei is tanúskodnak, ${ }^{76}$ Hydatius pedig ezt megerősítve egyáltalán nem említ olyan eseteket, amikor a szvévek rómaiakat vagy vallási csoportokat üldöznének. Éppen ezért nem gondoljuk, hogy Hydatiusnak nagy bátorságra lett volna szüksége ahhoz, hogy elhagyja a püspöki székét az asturicai manicheusok felkutatása érdekében, ráadásul mindezt a város püspöke, Thoribius kérésére tette, az intézkedés pedig összhangban volt Hydatius elveivel. ${ }^{77}$ Ezek alapján jól látszik, hogy a gallaeciai püspökök többsége nem nyíltan fordult szembe a pápa akaratával, hanem inkább közömbösséget tanúsítva egyszerüen nem tett lépéseket az ortodoxia védelmében, meghiúsítva ezzel Thoribius és Hydatius kitartó munkáját, az emeritai Antoninus viszont valószínűleg továbbra is lelkesen folytatta az eretnekség elleni küzdelmet, mert 448-ra Lusitania egész területéről sikerült kiüznie a manicheus elveket valló Pascentiust. ${ }^{78}$

Ahogyan láttuk, Hydatius feltűnően sokat foglalkozik a priscillianusok mozgalmával, ezt viszont azzal is magyarázhatjuk, hogy meg szeretné győzni a többi püspököt arról, hogy ha a legnagyobb egyházi vezetők el tudták utasítani Priscillianus téves tanítását, akkor Gallaecia püspökeinek és híveinek is ezt a példát kell követnie. ${ }^{79}$ Priscillianus püspökké választásakor Hydatius nem titkolja, hogy az egyházi vezetők egy része támogatta őt a gonoszságban, de büszkeséggel tölti el, hogy Rómában sem Damasus, sem Ambrosius nem hallgatta meg őt, Priscillianus még a színük elé sem kerülhetett, Maximus pedig először hiába adott helyet a fellebbezésnek, később éppen

\footnotetext{
${ }^{72}$ Hyd. 122. Balconius tevékenységéről bővebben: Avit. Ep. ad Balc., in PL 41.805-818; ToRREs RodRíGUEZ 1977. 92-97; LóPEZ PEREIRA 1998. 29-30.

${ }^{73}$ THOMPSON 1982. 196; KULIKOWSKI 2010. 188

${ }^{74}$ Az újabb kutatások szerint Bracara és Emerita katonai-politikai szempontból egyaránt a Szvév Királyság fővárosának tekinthető, vö. LóPEZ QuirogA - MARTínEZ TEJERA 2017. 438.

${ }^{75}$ TORRES RodríGUEZ 1977. 112; DíAz 1986. 363-364.

${ }^{76}$ LÓPEZ QuirogA - MARTíNEZ TejerA 2017. 481-482. Az 5-6. századi gallaeciai kereszténység működését igazolják a Lucus és Bracara környékén talált ikonográfiai emlékek és temetkezési feliratok, vö. LóPEZ QUIROGA - MARTíNEZ TEJERA 2017. 129; 160-161; 164-165; 171-172; 204.

${ }^{77}$ BuRgess 1988. 219; 203.

${ }^{78}$ Burgess 1988. 202; Muhlberger 1990. 239; Hyd. 130.

${ }^{79}$ Muhlberger 1990. 236.
} 
az ő parancsára végezték ki Priscillianust és követőit. ${ }^{80}$ Hydatius viszont érdekes módon nagyon keveset mond Priscillianus kivégzésének körülményeiről, talán az eljárás körüli botrány és a politikai hatalom beavatkozása miatt nem mert állást foglalni az ügyben. Többször is utalt ugyan Ambrosius és Martinus Turonensis jótéteményeire, de valószínűleg nem a priscillianusokkal kapcsolatos tevékenységükre gondolt, mivel érthető okokból sehol sem említi, hogy éppen ők tiltakoztak volna a kivégzések ellen, és hogy nekik köszönhetően váltották le az ítélet meghozatalában közremüködő ortodox püspököket. Már a 306 körül megtartott elvirai zsinat aktái is arról tanúskodnak, hogy a hispaniai keresztények egy része ,erkölcsi lazaságá”-'ról volt híres, ezért sem meglepő, hogy a 400 körüli toletumi zsinaton már szükség volt egyházfegyelmi rendelkezésekre is, amelynek hatására jó néhány püspök visszatért a katolikus egyházba. ${ }^{81}$ Bár a priscillianusok üldözése egyre nagyobb méreteket öltött, még több évtizeddel később is jó néhányan rokonszenvezhettek a mozgalommal, mert 447-ben Leo pápa kénytelen volt az ellenük szóló írásokat és más rendelkezéseket elküldeni a hispaniai püspökökhöz, ezenfelül még Sulpicius Severus is a priscillianusokig tárgyalja az eseményeket krónikájában. ${ }^{82}$

Az egyházi vezetők számára azonban nemcsak az ortodoxia egységes védelmezése és az eretnekmozgalmakkal szembeni határozott fellépés jelentett nehézséget, hanem a püspökök közötti meggondolatlan kinevezések is problémát okoztak az egyház belső életében. ${ }^{83}$ Hydatius több olyan botrányos püspökválasztásról tudósít, amelyik azt igazolja, hogy a gallaeciai egyház nem volt egységes, és gyakran az igazhitü püspökök is egymás ellen vívtak hatalmi harcokat, ahogyan Sulpicius Severus is arról tájékoztatja olvasóit, hogy a püspökök irigysége és hataloméhsége folyamatosan nyugtalanította és alaposan összezavarta a keresztény híveket. ${ }^{84}$ Először 433-ban találkozunk püspökválasztással kapcsolatos botránnyal, amikor Lucus püspöki székéből leváltották Agrestiust, helyére pedig a püspök akaratával szemben Pastort és Syagriust választották. Hydatius semmit nem mond a leváltás okairól és a szóban forgó személyek vallási nézeteiről, de Tranoy névazonosságok alapján feltételezi, hogy Agrestius szimpatizált a priscillianusokkal, Pastor és Syagrius pedig a katolikus hitet próbálta képviselni priscillianusellenes írásaival. ${ }^{85}$ Valószínűbb magyarázatnak tünik azonban Burgess feltevése, mely szerint az alapján, hogy a város püspökének akaratával szemben iktatták be az új vezetőket, és hogy Agrestius priscillianusként aligha vehetett volna részt a 441-es arausiói zsinaton, Agrestiust tartja ortodoxnak, a másik két, feltehetően priscillianus püspökről viszont nem közöl információkat. ${ }^{86}$

Miután 441-ben a szvévek elfoglalták Hispalist, Agrestiushoz hasonló módon váltották le Sabinust, hogy Epiphanius ülhessen a püspöki székbe. Mivel Hydatius azt állítja, hogy a régi püspököt fondorlat útján távolították el helyéről, Epiphanius megválasztására pedig csellel került sor, Tranoy és Thompson joggal feltételezi, hogy Epiphanius a priscillianizmus híve volt, Sabinus pedig az ortodoxiát képviselte. ${ }^{87}$ Muhlberger ezen felül azt sem tartja kizártnak, hogy egy

\footnotetext{
${ }^{80}$ Hyd. 13; 16.

${ }^{81}$ Hyd. 8; 30; 25; VANYÓ 2007. 142-143.

${ }^{82}$ Hyd. 30; 127; Sulp. Sev. Chr. 2.51.

${ }^{83}$ Hyd. praef. 6.

${ }^{84}$ Sulp. Sev. Chr. 2.46.1; 2.51.5; WIESER 2016. 93-94.

${ }^{85}$ Hyd. 93; Tranoy 1974. 2.69; Chadwick 1976. 217; Thompson 1982. 195; Muhlberger 1990. 240.

${ }^{86}$ CCL 148.87.9; Chadwick 1976. 221-222; Burgess 1988. 220; López Quiroga - Martínez Tejera 2017.478.

${ }^{87}$ Hyd. 115-116; Tranoy 1974. 2.78-79; ThOMPSON 1982. 195; 303. 42. j.
} 
elégedetlenkedő csoport Hispalisban a város bukását kihasználva aktivizálta magát, hogy saját jelöltjét ültethesse a püspöki székbe, vagyis a rómaiak belső konfliktusaik rendezésére kihasználták a szvévek jelenlétét, de emellett elfogadhatónak tünik Burgess azon javaslata is, hogy a szvévek avatkoztak bele a püspökválasztásba, mert amikor 458-ban a gótok előrenyomultak Baeticában, Sabinus visszatérhetett száműzetéséből és újra Hispalis püspöke lett. ${ }^{88}$ Burgess a két eset kapcsán ugyanakkor arra a következtetésre jut, hogy ha az említett püspökök, Agrestius és Epiphanius valóban priscillianusok lettek volna, Hydatius mindenképpen tájékoztatta volna olvasóit erről az egyáltalán nem mellékes információról, ezért a püspökválasztással kapcsolatos vita eldöntése céljából nem szükséges őket feltétlenül kapcsolatba hozni a priscillianizmussal, ${ }^{89}$ bár a későbbiekben látni fogjuk, hogy Hydatiusnak akár érdekében is állhatott, hogy elhallgassa a püspökválasztásokkal kapcsolatos részleteket.

Gallaecia püspökségeinek irányítása mindenesetre az 5. században sem lehetett túl egyszerü feladat, mert a többi provinciához képest az itt működő püspököket az eretnek tanítások népszerüsége miatt kevésbé tudták erős kézzel irányítani, sok esetben még a püspöki tanácskozások megtartása és a korábbi zsinati határozatok érvényesítése is akadályba ütközött. ${ }^{90}$ Másrészről viszont Hydatius felhívja a figyelmünket arra, hogy püspöki kinevezése új lehetőségeket biztosított számára, hiszen vezető egyházi pozíciója révén, különösen a 430-440-es években valószínüleg sokat találkozott gallaeciabeliekkel és szvévekkel, követekkel és utazókkal egyaránt, így eljuthatott hozzá a pápai és a püspöki levelezések egy része, ${ }^{91}$ amelyek még akkor is jó forrásanyagot jelenthettek egy krónika megírásához, ha Hydatius csak jóval később kezdett bele annak megírásába.

Hydatius láthatóan tudatában volt annak a felelősségnek, amely a püspöki pozícióhoz mint közérdekű hivatali szolgálathoz kapcsolódott, éppen ezért büszkén vállalta az ezzel járó feladatokat. ${ }^{92}$ Példaként tekintett azokra az egyházatyákra, akik sikeresen vették fel a harcot különböző eretnekmozgalmakkal, és Gallaecia többi püspökétől is ehhez hasonló fegyelmet és lojalitást várt el. A krónikában a szvévek és a rómaiak együttélése egyfajta „,permanent conflict” formájában jelenik meg, ugyanakkor tudjuk, hogy leginkább a katolikus papság képviselői müködhettek együtt a szvév hatalommal, segítve ezzel az expanzív törekvéseiket és a császári hatalom fokozatos felmorzsolódását. ${ }^{93}$ A korábbi példák alapján egyértelmü, hogy Emerita és Arelate városában jó néhány püspök a helyi közösség élére állt és karizmatikus vezetőként segítette a lakosság mindennapjait, Gallaeciában viszont nem hallunk ilyen típusú interakciókról, Hydatius pedig valószínűleg kisebbségben volt vagy talán teljesen magára is maradt az eretnekek elleni küzdelemben. ${ }^{94}$

Ezek alapján valószínűsíthetjük, hogy Hydatius nemcsak azért részletezi saját püspöki tevékenységét, hogy a többi egyházi vezetőt is hasonló viselkedésre buzdítsa, hanem az olvasók előtt is igazolni szeretné, hogy ő milyen lelkiismeretesen harcol a katolikus hit védelmében és mennyire együttmüködik a felsőbb egyházi utasításokkal, ezáltal igyekszik példaképeihez hasonló sikereket

\footnotetext{
${ }^{88}$ Muhlberger 1990. 242; Pawlak 2007. 31; Burgess 1988. 218; vö. Hyd. 185; 187.

${ }^{89}$ Burgess 1988. 220.

${ }^{90}$ Leo Ep. 15, praef.; Thor. Ep. 2, in PL 54.693; BuRgeSs 1988. 203.

${ }^{91}$ Hyd. praef. 6; Burgess 1988. 34.

${ }^{92}$ ANGENENDT 2008. 71.

${ }^{93}$ BARBERO - Loring 2005. 164.

${ }^{94}$ Wood 2007. 517; MuHLBerger 1990. 244.
} 
és népszerűséget elérni. Burgess azonban felhívja a figyelmünket két ezzel kapcsolatos problémára. Mivel Hydatius nem mond semmit a vele együtt vizsgálódó Caeponiusról, elképzelhető, hogy ő nem volt annyira elszánt és igazhitü, mint Hydatius, vagy egyszerüen nem akart szembekerülni a priscillianusokkal. Az is különös, hogy Hydatius a felkutatott eretnekekkel szemben semmilyen önálló lépést nem tett, csak az előírások szerint jelentést küldött Emeritába, talán mert félt a priscillianusok vagy a manicheusok bosszújától. Ezek ismeretében már meg sem lepődünk azon, hogy 447 után nem is említi a priscillianusok mozgalmát, holott korábban láttuk, hogy népszerűségük még ebben az időszakban is nagy problémát jelentett Gallaeciában. Nem tudjuk, hogy 447 után hogyan viszonyultak a szvévek az ortodox római lakossághoz, mindenesetre Aquae Flaviae városában nem látunk nagy püspöki győzelmeket az eretnekség képviselőivel szemben. ${ }^{95}$ Nincsenek információnk arról sem, hogy Hydatius saját működési területén akár csak egyetlen alkalommal is konkrét lépéseket tett volna a priscillianusok ellen, de lehet, hogy csak azért nem említi ezeket a krónikában, mert az erre irányuló törekvései meghiúsultak vagy kudarccal végződtek.

Hydatius életének és püspöki működésének egyik fordulópontja lehetett, amikor 460. július 26-án három besúgó ösztönzésére Frumarius szvév csapatai elfogták őt és feldúlták Aquae Flaviae kolostorát a környező területekkel együtt. Novemberben, háromhónapnyi fogság után valószínủleg a gallaeciabeliek és a szvévek közötti látszólagos béke jegyében szabadon engedték Hydatiust, az viszont nem derül ki, hogy miért akarták őt a besúgók félreállítani és később milyen okból ellenezték a szabadon bocsátását. ${ }^{96} \mathrm{Az}$ 5. században a városok mindennapi életének biztosítása és az adminisztratív tevékenységek irányítása egyre inkább a püspökök feladatává vált, ezért a barbár vezetők egy város megtámadásakor gyakran a püspökökkel tárgyaltak, a megszállás után pedig velük alakították ki a két nép közötti együttélés feltételeit. ${ }^{97}$ Ennek tükrében elfogadhatónak tűnik Muhlberger magyarázata, mely szerint Hydatius nyilvánosan kiállt a rómaiak érdekei mellett és szimpatizált a birodalmi irányítással, ezért megpróbálták őt eltávolítani a közéletből ${ }^{98}$ Torres Rodríguez és Tranoy viszont inkább azt feltételezi, hogy a besúgók arianusok vagy priscillianusok lehettek, ezért vallási okok miatt fordulhattak az ortodox püspök ellen, ${ }^{99}$ különösen mert azt is tudjuk, hogy a priscillianusok gyakran a püspökök egyházon belüli hatalmát is megkérdőjelezték. ${ }^{100}$ Mivel Hydatius is említi, hogy nem Frumarius vagy a szvévek, hanem a három besúgó kezdeményezte az elfogását, bizonyítékok nélkül is megfontolandó Burgess azon feltevése, hogy a nevük alapján római származású besúgók elkeseredésükben átállhattak a szvévek oldalára, és mivel priscillianusok voltak és Hydatius konkrét lépésekkel vagy csak az igazhitűek bátorításával fellépett ellenük, bosszúból próbálták meg őt félreállítani. ${ }^{101}$

\footnotetext{
${ }^{95}$ Burgess 1988. 203-204; 223-225.

${ }^{96}$ Hyd. 196; 199; 202.

${ }^{97}$ HoRVÁth 1999. 48.

${ }^{98}$ Muhlberger 1990. 226.

99 Torres Rodríguez 1956. 783-784; 792-793; Tranoy 1974. 1.16; 2.114. Megfontolandó még Burgess véleménye, mely szerint Hydatius félhetett az asturicai vizsgálat során felkutatott eretnekek bosszújától, vö. BURGESS 1988. 203.

${ }^{100}$ LÓPEZ Quiroga - MARTínez TeJERA 2017. 482.

${ }^{101}$ Burgess 1988. 204.
} 
Mindez azt is megmagyarázná, hogy Hydatius miért utasítja el teljesen a barbárokkal való együttmüködés minden formáját, hiszen ő maga is ennek az interakciónak, vagy ahogyan fogalmaz, besúgásnak esett áldozatul. Ha első látásra úgy tűnik, hogy a krónika domináns témája a barbárok tevékenysége, és az egyházi kérdésekről sokkal kevesebb szó esik, ${ }^{102}$ mégsem kételkedhetünk abban, hogy Hydatius több évtizedes püspöki müködése alatt a szvévek által megszállt területen történtek olyan egyházi élettel kapcsolatos események, amelyeket érdemes lett volna feljegyezni a krónikában, hacsak nem kényszerült arra Hydatius, hogy félelemből vagy a saját magáról alkotott pozitív kép megőrzése céljából elhallgassa őket.

Hydatius tehát széles rálátást biztosít az 5. századi népszerü eretnekmozgalmakra, de a tanítások értelmezése helyett azt próbálja megmutatni az olvasóinak, hogy ezek milyen módon gyengítették az ortodoxia helyzetét és hogyan sodorták válságba a birodalmi irányítást. Hydatius már fiatal püspökként ismert lehetett az ortodoxia melletti elkötelezettségéről, emiatt kérte fel őt Thoribius és Leo pápa a priscillianusokkal és a manicheusokkal szembeni nyomozásra, és talán ez is eredményezhette azt, hogy 460-ban megpróbálták őt eltávolítani a közéletből. Bár nem tudunk Hydatius önálló püspöki intézkedéseiről a többségében priscillianus Gallaeciában, talán mert nézetei miatt megfélemlítették vagy próbálkozásai kudarccal végződtek, tevékenysége kétségtelenül megcáfolja azt a feltételezést, hogy a hispán-rómaiak a barbár megszállások alatt teljes közömbösséget mutattak saját helyzetük javítása érdekében.

\section{FELHASZNÁLT IRODALOM}

\section{Források}

CSEL = Corpus Scriptorum Ecclesiasticorum Latinorum. Wien. 1866-1886.

Hyd. = Hydatii Lemici continuatio chronicorum Hieronymianorum ad a. CCCCLXVIII. In TH. MommSEN (ed.): MGH AA XI. CM 2. Berlin, 1894. 1-36. = Hydatii Limici Chronica Subdita. In R. W. Burgess (transl.): The Chronicle of Hydatius and the Consularia Constantinopolitana. Oxford, 1993. 69-123. = Széll G. (ford.): Püspöki tudósítás Hispaniából. Hydatius: Chronica. In SzÉKELY M. - IllÉs I. Á. (szerk.): Késő római szöveggyüjtemény. Szeged, 2013. 347-400.

Leo Ep. $=$ C. SIlva-TAROUCA (ed.): S. Leonis Magni epistulae contra Eutychis haeresim. Series theologica 15, 20. Rome. 1934-1935.

Oros. = C. ZANGEMEISTER (ed.): Pauli Orosii historiarum adversum paganos libri VII. In CSEL 5. Berlin, 1882. = M.-P. Arnaud-Lindet (transl.): Orose: Histoires contre les païnes. Paris, 1990-1991.

$\mathrm{PL}=$ J. P. Migne (ed.): Patrologiae Latinae cursus completus. Vols. 1-222. Paris, 1844-1865, 1878-18902.

Sulp. Sev. Chr. = C. HALM (ed.): Sulpicii Severi chronicorum libri. In CSEL 1. Vienna, 1866. 3-105.

\footnotetext{
${ }^{102}$ PAWLAK 2007. 31.
} 


\section{Szakirodalom}

Angenendt, A. (2008): A kora középkor: A nyugati kereszténység 400-tól 900-ig. Budapest.

ARIAS, J. C. (2007): Identity and Interactions: The Suevi and the Hispano-Romans. Virginia.

Augusto, D. P. (2016): Exim in Gallaeciam Priscillianistarum Haeresis Invasit. The Success of Priscillianism in Gallaecia Following the Trials at Trier. Klio 98/2. 634-652.

Barbero, A. - Loring, M. I. (2005): The Formation of the Sueve and Visigothic Kingdoms in Spain. In P. Fouracre (ed.): The New Cambridge Medieval History. Vol. 1.: c. 500-c. 700. Cambridge. 162-192.

Burgess, R. W. (1988): Hydatius: A Late Roman Chronicler in Post-Roman Spain. An Historiographical Study and New Critical Edition of the Chronicle. D. Phil. thesis. Oxford.

Burgess, R. W. (1993): The Chronicle of Hydatius and the Consularia Constantinopolitana. Oxford.

Burrus, V. (1995): The Making of a Heretic. Gender, Authority and the Priscillianist Controversy. Berkeley-Los Angeles-Oxford.

CAmpos, J. (1984): Idacio, obispo de Chaves, su Cronicón. Salamanca.

Candelas-Colodrón, C. (2004): Análisis de la figura de Hidacio de Chaves a través de los condicionantes socioeconómicos, políticos y culturales de la Gallaecia del siglo V. El Cronicón. Coruña.

Cardelle de Hartmann, C. (1998): Ortodoxos y priscilianistas en la época sueva. In E. Koller H. Laitenberger (eds.): Suevos-Schwaben. Das Königreich der Sueben auf der Ibersichen Halbinsel (411-585). Coloquio Interdisciplinar. Universidade do Minho, Braga, 4-6 March 1996. Tübingen. 81-104.

Chadwick, H. (1976): Priscillian of Avila. The Occult and the Charismatic in the Early Church. Oxford.

Chadwick, H. (1999): A korai egyház. Ford. Ertsey K. - Tornai Sz. Budapest.

Cortázar, F. G. DE - Vesga, J. M. G. (2001): Spanyolország története. Ford. Lakatos Zs. Renteria A. Budapest.

D’Emilio, J. (2015): Culture and Society in Medieval Galicia. A Cultural Crossroads at the Edge of Europe. Boston.

DíAz, P. C. (1986): La modalidad del asentamiento suevo y sus consecuencias. Studia Zamorensia 7. 353-365.

EsCRIBANO, V. (2005): Heresy and Orthodoxy in Fourth-Century Hispania: Arianism and Priscillianism. In K. BOWES - M. KULIKOWSKI (eds.): Hispania in Late Antiquity: Current Perspectives. Leiden-Boston. 121-149.

García Villada, Z. (1932): Historia Eclesiástica de España. Vol. 1. Madrid. 
HoRvÁth E. (1999): Az arianizmus és a barbár államalakulatok. Studia Miskolcinensia 3. 45-52. HorvÁth E. (2004): Priscillianus esete Maximus császárral és Ambrus püspökkel. Publicationes Universitatis Miskolciensis. Sectio Philosophica 9/3. 67-81.

Kulikowski, M. (2010): Late Roman Spain and its Cities. Baltimore-London.

LÓPEZ PereirA, J. E. (1998): La Galicia sueva vista por los escritores indígenas contemporáneos. In E. Koller - H. Laitenberger (eds.): Suevos-Schwaben. Das Königreich der Sueben auf der Ibersichen Halbinsel (411-585). Coloquio Interdisciplinar. Universidade do Minho, Braga, 4-6 March 1996. Tübingen. 21-36.

López Quiroga, J. - Martínez Tejera, A. M. (2017): In Tempore Sueborum. El Tiempo de los Suevos en la Gallaecia (411-585). El Primer Reino Medieval de Occidente. Catálogo de Exposición. Transl. C. Ilie. Ourense. In https://www.scribd.com/document/387581132/Catalogo-In-TemporeSueborum; http://www.academia.edu/37321555/IN_TEMPORE_SUEBORUM._The_time_ of_the_Suevi_in_Gallaecia_411-585_AD_._Exhibition_Catalogue_English_(2018.12.30.)

LÖHR, W. (2007): Western Christianities. In A. CASIDAY - F. W. NorRIs (eds.): The Cambridge History of Christianity. Vol. 2: Constantine to c. 600. Cambridge. 9-51.

LYMAN, J. R. (2007): Heresiology: The Invention of 'Heresy' and 'Schism'. In A. CASIDAY F. W. Norris (eds.): The Cambridge History of Christianity. Vol. 2: Constantine to c. 600. Cambridge. 296-316.

Maldonado, P. C. (2005): Angelorum participes: The Cult of the Saints in Late Antique Spain. In K. Bowes - M. Kulikowski (eds.): Hispania in Late Antiquity: Current Perspectives. Leiden-Boston. 151-188.

Molé, C. (1975): Uno storico del V secolo: il vescovo Idazio. Parte 2. Siculorum Gymnasium 28. 58-139.

Munlberger, S. (1990): The Fifth-Century Chroniclers. Prosper, Hydatius and the Gallic Chronicler of 452. Leeds.

PawlaK, M. (2007): Hydace et le Désordre de son Temps. In D. BrodKA - M. STAChura (eds.): Continuity and Change. Studies in Late Antique Historiography. Electrum 13. Kraków. 29-37.

RANDERs-Pehrson, J. D. (1993): Barbarians and Romans. The Birth Struggle of Europe, AD 400-700. Norman-London.

Riché, P. (2016): Oktatás és müvelődés a barbár Nyugaton (6-8. század). Ford. Ádám A. Sághy M. Budapest.

SÁRY P. (2009): Pogány birodalomból keresztény birodalom. A Római Birodalom kereszténnyé válása a Codex Theodosianus tükrében. Budapest.

Segesváry L. (1994): Az egyháztörténelem alapvonalai. Debrecen. 58-86.

SPÄT E. (1998): Priscillianus tanai az egyházatyák tükrében. Antik Tanulmányok 42/1-2. 137-152. 
SzÁNTÓ K. (1983): A katolikus egyház története. Vol. 1. Budapest.

SzÉKely M. (2018): Pacatus: Theodosius császár dicsőítése. Ókor XVII/1. 101-107.

SzÉLL G. (2007): Hydatius, az V. század gallaeciai krónikása. In Panégyris. Szerk. MÉszÁros T. JUTAI P. Budapest. 53-56.

SzÉLl G. (2015): A hispaniai Szvév Királyság felemelkedése (409-456). In SzÉKELY M. ILLÉs I. Á. (szerk.): Tanulmányok a hetven éves Wojtilla Gyula tiszteletére. AAASzeged Suppl. 14. Szeged. 113-124.

SzÉLL G. (2017): The Crisis of the Kingdom of the Suebi: Relations with the Visigoths and the Romans (456-468). Chronica 17. 91-99.

Thompson, E. A. (1982): Romans and Barbarians: The Decline of the Western Empire. Madison. TORRES RodríGUEZ, C. (1956): El cronicon de Hidacio: Consideraciones. Compostellanum 1. 765-801. Torres Rodríguez, C. (1977): El reino de los suevos (or Galicia sueva). La Coruña.

Tranoy, A. (1974): Hydace: Chronique. Vols. 1-2. Sources Chrétiennes 218-219. Paris.

VANYó L. (1999): A III-IV. század szentjei. Budapest.

VANYó L. (2007): Az ókeresztény egyház irodalma I: Az első három század. Budapest.

Vilella, J. (1999): Idacio, un cronista de su tempo. Compostellanum 44. 39-54.

Vives, J. (1963): Concilios Visigóticos e Hispano-romanos. Barcelona - Madrid.

WIESER, V. (2016): Sulpicius Severus Krónikája és a 4. századi világvégevárás. Ford. Barabás G. Világtörténet 38/1. 87-118.

Wood, I. N. (2007): The North-Western Provinces. In A. CAMERON - B. WARd-PERKINS M. Whitby (eds.): The Cambridge Ancient History. Vol. 14: Late Antiquity: Empire and Successors, AD 425-600. Cambridge. 497-524. 